\title{
Correlation between estrogen receptor $\beta$ expression and the curative effect of endocrine therapy in breast cancer patients
}

\author{
LIYING GUO $^{1}$, YU ZHANG ${ }^{2}$, WEI ZHANG ${ }^{3}$ and DILIMINA YILAMU ${ }^{1}$ \\ ${ }^{1}$ Department of Breast Cancer, Digestive and Vascular Center, The First Affiliated Hospital of Xinjiang Medical University, \\ Urumqi, Xinjiang 830054; ${ }^{2}$ Department of General Surgery, Yantai Affiliated Hospital of Binzhou Medical University, \\ Yantai, Shandong 264100; ${ }^{3}$ Department of Pathology, The First Affiliated Hospital of Xinjiang Medical University, \\ Urumqi, Xinjiang 830054, P.R. China
}

Received November 8, 2013; Accepted March 11, 2014

DOI: $10.3892 /$ etm.2014.1634

\begin{abstract}
The aim of the present study was to investigate the association between the expression levels of estrogen receptor (ER) $\beta$ and the curative effect of endocrine therapy in breast cancer patients. Cancer tissues were collected from 583 breast cancer patients between January 2000 and December 2010 and used for analysis. ER $\beta$ expression levels were determined using immunohistochemical staining. The Kaplan-Meier method was used for survival analysis and the log-rank test was conducted for difference analysis between survival times. In addition, Cox multivariate analysis was performed to analyze prognostic factors for breast cancer. In the immunohistochemical staining assay, a positive ER $\beta$ expression rate of $<10 \%$ was defined as ER $\beta$ low expression, while $>10 \%$ was defined as ER $\beta$ high expression. In patients expressing low levels of $\mathrm{ER} \beta$, the median tumor-free survival time of the patients who received endocrine therapy was significantly higher compared with that of the patients who did not receive endocrine therapy. By contrast, in patients with high ER $\beta$ expression levels, there was no significant difference in the median tumor-free survival time between the patients who received endocrine therapy and those who did not. In addition, compared with ER $\beta$ low expression patients, ER $\beta$ high expression patients had a significantly lower median tumor-free survival time. Furthermore, ER $\beta$ expression, human epidermal growth factor receptor 2 expression, tumor size, lymph node metastasis, postoperative chemotherapy, radiotherapy and endocrine therapy were identified to be independent prognostic factors for breast cancer. Therefore, high ER $\beta$ expression in breast cancer indicates poor prognosis for endocrine therapy.
\end{abstract}

Correspondence to: Dr Liying Guo, Department of Breast Cancer, Digestive and Vascular Center, The First Affiliated Hospital of Xinjiang Medical University, 137 South Liyushan Road, Urumchi, Xinjiang 830054, P.R. China

E-mail: gejsy318@126.com

Key words: breast cancer, estrogen receptor $\beta$, curative effect

\section{Introduction}

Breast cancer is a hormone-dependent tumor that involves the interaction of estrogen and its specific receptors. Estrogen receptor (ER) $\beta$, as reported by Kuiper et al (1), was initially identified in the cDNA library of rat prostate cells and is a subtype of the ER superfamily. ER $\beta$ is known to be widely expressed in normal cells and tumor tissues of humans and rats. The expression levels of ER $\beta$ in ovarian, liver, prostate, small intestine and colorectal cancers have been reported to be associated with tumor occurrence, development and malignancy (2). Notably, ER $\beta$ is of great significance for breast cancer and ER $\beta$ expression levels in breast cancer are closely associated with the curative effect of postoperative endocrine therapy (3).

Endocrine therapy is an effective method for the treatment of estrogen-sensitive breast cancer. Esslimani-Sahla et al (4) hypothesized that ER $\beta$ protein levels in breast cancer are associated with the efficacy of endocrine therapy. Hopp et al (5) found that ER $\beta$ was highly expressed in endocrine-resistant breast cancer cells. By contrast, Borgquist et al (6) reported that low ER $\beta$ expression resulted in a poor prognosis of endocrine therapy. Therefore, the role of ER $\beta$ in endocrine resistance remains controversial.

In the present study, the association between ER $\beta$ expression and the efficacy of endocrine therapy in breast cancer was systematically investigated. Cancer tissues from 598 patients with breast cancer were used in the study and the expression levels of ER $\beta$ were determined by immunohistochemistry. Survival analysis was conducted between patients with ER $\beta$ low or high expression and patients who received or did not receive endocrine therapy. In addition, the prognostic factors for breast cancer were analyzed by Cox multivariate analysis.

\section{Materials and methods}

Clinical data. In total, 598 patients with pathologically confirmed invasive breast cancer were enrolled in the study. All individuals were diagnosed and treated in the First Affiliated Hospital of Xinjiang Medical University (Ürümqi, China) between January 2000 and December 2010. The clinical features of the patients are shown in Table I. Patients 
received follow-ups for 2-10 years. During the follow-up period, 15 patients were censored due to the loss of contact during the follow-up period or prior to the study cut-off point, or due to mortality from other causes.

Prior written and informed consent was obtained from every patient and the study was approved by the Ethics Review Board of Xinjiang Medical University.

Immunohistochemistry. Breast cancer tissue specimens were fixed in $10 \%$ formaldehyde for $24 \mathrm{~h}$ and then embedded in paraffin. The specimens were then sliced into $3-\mu \mathrm{m}$ sections. Following dewaxing and rehydrating in graded alcohols, sections were incubated with anti-ER $\beta$ primary antibodies. An ER $\beta$ positive sample was used as a positive control. In the negative control, the primary antibody was replaced with phosphate-buffered saline. The anti-ER $\beta$ antibodies and the working solution were purchased from Fuzhou Maixin Biotechnology Development Co., Ltd. (Fuzhou, China).

Determination of ER $\beta$ expression levels. Cells with brown staining in the nucleus were considered ER $\beta$ positive cells. Five fields at high-magnification were randomly selected. The $\mathrm{ER} \beta$ positive rate was the ratio of the number of $\mathrm{ER} \beta$ positive cells to the total number of cells in each field. An ER $\beta$ positive rate $<1 \%$ was defined as ER $\beta$ negative (-). A positive rate between 1 and $10 \%$ was defined as ER $\beta$ weak positive (+) and an ER $\beta$ positive rate between 10 and $50 \%$ was defined as ER $\beta$ positive $(++)$. Finally, an ER $\beta$ positive rate $>50 \%$ was defined as ER $\beta$ strong positive $(+++)$. Cells defined ER $\beta(-)$ and $(+)$ were considered to be ER $\beta$ low expression cells, while cells defined $\operatorname{ER} \beta(++)$ and $\operatorname{ER} \beta(+++)$ were considered to be $\operatorname{ER} \beta$ high expression cells.

Statistical analysis. SPSS statistical software, version 17.0 (SPSS, Inc., Chicago, IL, USA) was used for statistical analysis. Kaplan-Meier survival curves were constructed for survival analysis and the log-rank test was used to determine the differences in survival. Cox multivariate analysis was also performed to analyze prognostic factors. $\mathrm{P}<0.05$ was considered to indicate a statistically significant difference.

\section{Results}

Expression of ER $\beta$ in breast cancer. The expression levels of ER $\beta$ in the breast cancer tissue samples were analyzed by immunohistochemical staining. Representative results are shown in Fig. 1. Cells with brown particles in the nucleus were ER $\beta$ positive cells. There were no cells with brown staining visible in Fig. 1A, indicating that ER $\beta$ expression was negative. However, in Fig. 1B-D, certain cells were positively stained, indicating a positive expression of ER $\beta$. Cells in which the expression of ER $\beta$ was indicated were counted and the positive expression rate was calculated. Weak expression of ER $\beta$ with a positive rate of $<10 \%$ is shown in Fig. 1B. Positive expression of ER $\beta$ with a positive rate between 10 and $50 \%$ is demonstrated in Fig. 1C and high expression of ER $\beta$ with a positive rate $>50 \%$ is shown in Fig. 1D. Cells that were classified as $\operatorname{ER} \beta(-)$ or (+) were defined as ER $\beta$ low expression cells, while cells that were classified as $\operatorname{ER} \beta(++)$ or $(+++)$ were defined as ER $\beta$ high expression cells.
Table I. Clinical features of the breast cancer patients.

\begin{tabular}{|c|c|}
\hline Clinical features & Cases, n $(\%)$ \\
\hline \multicolumn{2}{|l|}{ Age, years } \\
\hline$\leq 49$ & $296(50.8)$ \\
\hline$>50$ & $287(49.2)$ \\
\hline \multicolumn{2}{|l|}{ Menses } \\
\hline Menostasis & $305(52.3)$ \\
\hline Non-menostasis & $278(47.7)$ \\
\hline \multicolumn{2}{|l|}{ Tumor size, $\mathrm{cm}$} \\
\hline$\leq 2$ & $220(37.7)$ \\
\hline$>2, \leq 5$ & $289(49.6)$ \\
\hline$>5$ & $74(12.7)$ \\
\hline \multicolumn{2}{|l|}{ Histological grade } \\
\hline Grade I & $108(18.5)$ \\
\hline Grade II & $328(56.3)$ \\
\hline Grade III & $147(25.2)$ \\
\hline \multicolumn{2}{|l|}{ Clinical stage } \\
\hline Stage 0 & $193(33.1)$ \\
\hline Stage I & $280(48.0)$ \\
\hline Stage II & 110 (18.9) \\
\hline \multicolumn{2}{|c|}{ Lymph node metastasis } \\
\hline Negative & $322(55.2)$ \\
\hline Positive & $261(44.8)$ \\
\hline \multicolumn{2}{|l|}{$\mathrm{ER} \beta$ expression } \\
\hline Negative & $460(78.9)$ \\
\hline Positive & $123(21.1)$ \\
\hline \multicolumn{2}{|l|}{ ER $\alpha$ expression } \\
\hline Negative & $391(67.1)$ \\
\hline Positive & $192(32.9)$ \\
\hline \multicolumn{2}{|l|}{ HER-2 } \\
\hline Negative & $326(55.9)$ \\
\hline Positive & $257(44.1)$ \\
\hline \multicolumn{2}{|l|}{ Chemotherapy } \\
\hline Yes & $497(85.2)$ \\
\hline No & $86(14.8)$ \\
\hline \multicolumn{2}{|l|}{ Radiotherapy } \\
\hline Yes & $388(66.6)$ \\
\hline No & $195(33.4)$ \\
\hline \multicolumn{2}{|l|}{ Endocrine therapy } \\
\hline Yes & $254(43.6)$ \\
\hline No & $329(56.4)$ \\
\hline
\end{tabular}

ER, estrogen receptor; HER-2, human epidermal growth factor receptor.

Median tumor-free survival time is longer in patients with low ER $\beta$ expression receiving endocrine therapy. To determine the effect of ER $\beta$ expression on the efficacy of endocrine therapy, survival analysis was performed using the Kaplan-Meier method. Differences in survival time were analyzed with the log-rank test. Firstly, the tumor-free survival times in 
A

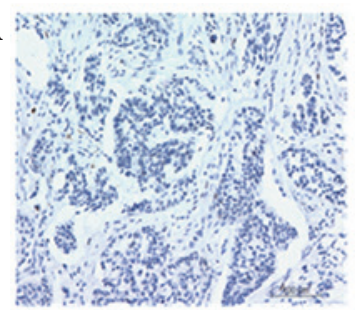

B

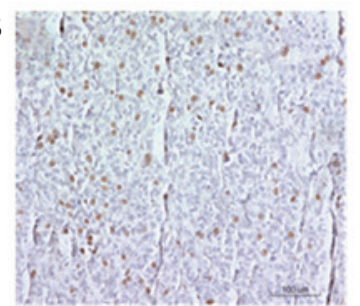

C

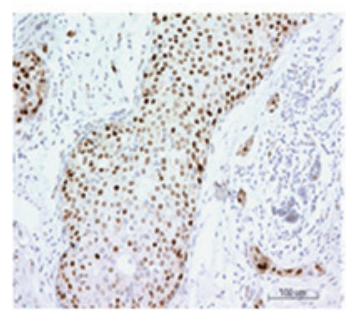

D

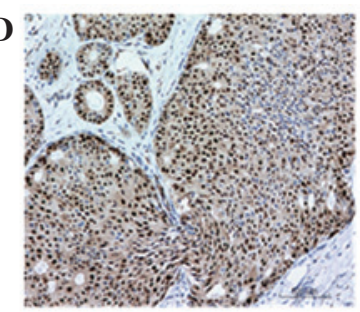

Figure 1. Expression analysis of ER $\beta$ in breast cancer tissues using immunohistochemistry (magnification, $\mathrm{x} 100)$. Representative images are shown and cells with brown staining in the nucleus were considered ER $\beta$ positive cells. Scale bar, $100 \mu \mathrm{m}$. (A) ER $\beta$ negative cells; (B) ER $\beta$ weak positive expression cells with a rate of $<10 \%$; (C) ER $\beta$ positive expression cells with a rate between 10 and 50\%; (D) ER $\beta$ high expression cells with a rate of $>50 \%$. ER, estrogen receptor.

A

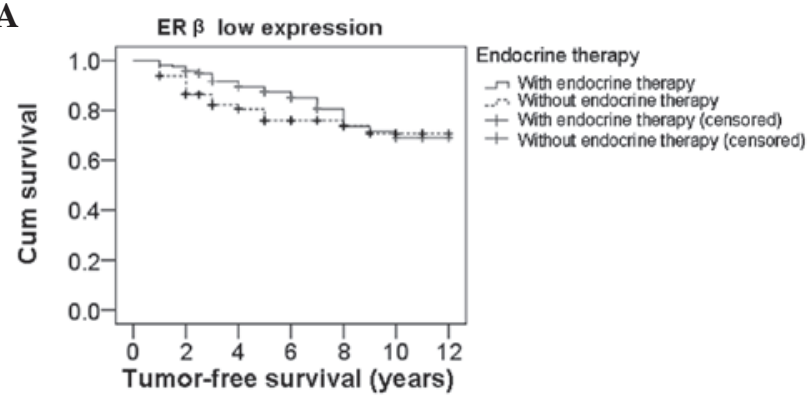

B

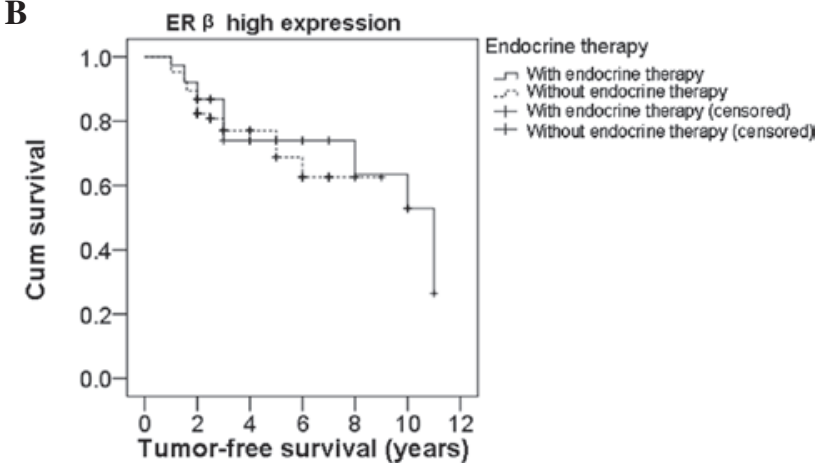

Figure 2. Kaplan-Meier survival analysis of breast cancer patients who received or did not receive endocrine therapy. Differences in survival time were analyzed with the log-rank test. Survival curve of (A) low and (B) high ER $\beta$ expression breast cancer patients who received or did not receive endocrine therapy. ER, estrogen receptor.

ER $\beta$ low expression patients who received or did not receive endocrine therapy were analyzed. The survival curves of ER $\beta$ low expression patients are shown in Fig. 2A. The median tumor-free survival time in patients that received endocrine therapy was 10.11 years, while in patients that did not receive endocrine therapy, the median tumor-free survival time was 9.56 years. Statistically, the difference between these two groups was significant $(\mathrm{P}=0.038)$. Next, tumor-free survival times were analyzed in ER $\beta$ high expression patients who did or did not undergo endocrine therapy. Fig. $2 \mathrm{~B}$ shows the survival curves of ER $\beta$ high expression patients. In ER $\beta$ high expression patients, the median tumor-free survival time of patients that received endocrine therapy was 8.31 years, while the median tumor-free survival time of patients that did not undergo endocrine therapy was 6.85 years. However, there was no statistically significant difference in median tumor-free survival time between these patients $(\mathrm{P}=0.583)$. Therefore, these results indicate that high ER $\beta$ expression levels in breast cancer patients impair the efficacy of endocrine therapy.

Patients with low ER $\beta$ expression levels have longer a median tumor-free survival time. To further investigate the role of ER $\beta$ expression in breast cancer patients, the tumor-free survival times were analyzed using the Kaplan-Meier method and the differences in survival time were analyzed with the log-rank test. The survival curves of ER $\beta$ low and high expression patients are shown in Fig. 3. The median tumor-free survival time in patients with low ER $\beta$ expression was 9.79 years, while in high ER $\beta$ expression patients, it was 8.01 years, which was significantly lower compared with that of the low ER $\beta$

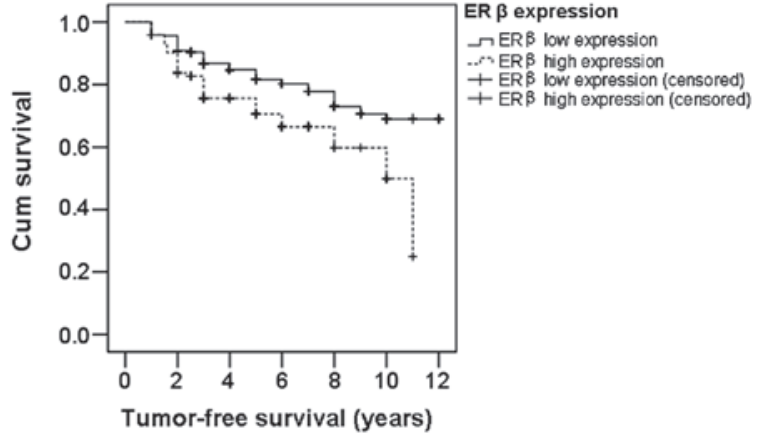

Figure 3. Kaplan-Meier survival analysis of breast cancer patients with low and high ER $\beta$ expression levels. Differences in survival time were analyzed with the log-rank test. ER, estrogen receptor.

expression patients $(\mathrm{P}=0.002)$. This result further indicates that patients with high ER $\beta$ expression levels have shorter tumor-free survival times and poor prognosis.

Analysis of prognostic factors for breast cancer. Prognostic factors for breast cancer were analyzed by Cox multivariate analysis. The analyzed factors were ER $\beta$ expression, tumor size, pathological grade, lymph node metastasis, chemotherapy, radiotherapy, endocrine therapy, ER $\alpha$ expression and human epidermal growth factor receptor (HER-2) expression. The results are shown in Table II. Independent prognostic factors for breast cancer were identified to be ER $\beta$ expression, tumor size, lymph node metastasis, chemotherapy, radiotherapy, endocrine therapy and HER-2 expression $(\mathrm{P}<0.05)$. However, 
Table II. Analysis of prognostic factors for breast cancer by Cox multivariate analysis.

\begin{tabular}{|c|c|c|c|c|c|c|}
\hline Risk factors & Regression coefficient & Standard error & Wald value & P-value & OR value & $95.0 \% \mathrm{CI}$ \\
\hline $\mathrm{ER} \beta$ & 0.581 & 0.212 & 7.519 & $0.006^{\mathrm{a}}$ & 1.787 & $1.18-2.707$ \\
\hline \multicolumn{7}{|l|}{ Tumor size } \\
\hline $2-5 \mathrm{~cm}$ & 0.782 & 0.285 & 7.543 & $0.006^{\mathrm{a}}$ & 2.187 & $1.251-3.822$ \\
\hline$>5 \mathrm{~cm}$ & 1.162 & 0.337 & 11.877 & $0.001^{\mathrm{a}}$ & 3.196 & $1.65-6.188$ \\
\hline \multicolumn{7}{|l|}{ Pathological grade } \\
\hline Grade II & 0.044 & 0.281 & 0.025 & 0.875 & 1.045 & $0.603-1.812$ \\
\hline Grade III & 0.192 & 0.309 & 0.385 & 0.535 & 1.212 & $0.661-2.222$ \\
\hline \multicolumn{7}{|c|}{ Lymph node metastasis } \\
\hline 1-4 pieces & 0.609 & 0.252 & 5.829 & $0.016^{\mathrm{a}}$ & 1.839 & $1.121-3.016$ \\
\hline 5-10 pieces & 1.116 & 0.289 & 14.902 & $<0.001^{\mathrm{a}}$ & 3.053 & $1.732-5.382$ \\
\hline$>10$ pieces & 1.101 & 0.313 & 12.361 & $<0.001^{\mathrm{a}}$ & 3.006 & $1.628-5.553$ \\
\hline Chemotherapy & 1.085 & 0.231 & 22.098 & $<0.001^{\mathrm{a}}$ & 2.96 & $1.883-4.653$ \\
\hline Radiotherapy & 0.556 & 0.208 & 7.135 & $0.008^{\mathrm{a}}$ & 1.744 & $1.16-2.623$ \\
\hline Endocrine therapy & 0.432 & 0.215 & 4.024 & $0.045^{\mathrm{a}}$ & 1.541 & $1.010-2.35$ \\
\hline $\mathrm{ER} \alpha$ & -0.332 & 0.228 & 2.118 & 0.146 & 0.717 & $0.459-1.122$ \\
\hline HER-2 & 0.428 & 0.194 & 4.871 & $0.027^{\mathrm{a}}$ & 1.534 & $1.049-2.243$ \\
\hline
\end{tabular}

${ }^{a} \mathrm{P}<0.05$. ER, estrogen receptor; HER-2, human epidermal growth factor receptor; OR, odds ratio; CI, confidence interval.

pathological grade and ER $\alpha$ expression were not determined to be prognostic factors $(\mathrm{P}>0.05)$.

\section{Discussion}

In the present study, tumor-free survival times were compared in breast cancer patients with high and low ER $\beta$ expression levels who received or did not receive endocrine therapy. The median tumor-free survival time was 10.11 years in ER $\beta$ low expression patients treated with endocrine therapy, while in ER $\beta$ low expression patients who did not undergo endocrine therapy, the median tumor-free survival time was 9.56 years. In ER $\beta$ high expression patients treated with endocrine therapy, the median tumor-free survival time was 8.31 years, while in ER $\beta$ high expression patients without endocrine therapy it was 6.85 years. There was a statistically significant difference $(\mathrm{P}=0.038)$ between patients who did or did not receive endocrine therapy when ER $\beta$ expression levels were low, whereas there was no significant difference when the ER $\beta$ expression levels were high $(\mathrm{P}=0.583)$. These results indicate that in $\mathrm{ER} \beta$ low expression patients, the efficacy of endocrine therapy was significant and the prognosis was better compared with that of the patients who did not receive endocrine therapy. By contrast, in ER $\beta$ high expression patients, the efficacy of endocrine therapy was not significant and the prognosis was similar to that of the patients who did not receive endocrine therapy. These results indicate that the prognosis was not improved by endocrine therapy in ER $\beta$ high expression patients. In addition, to a certain extent, ER $\beta$ high expression may be associated with endocrine resistance. The reason for resistance may result from the binding of ER antagonists with ER $\beta$, which activates the mitogen-activated protein kinase signaling pathway to facilitate the transcription of genes involved in cell proliferation and migration (7).
In addition, ER $\beta$ has been reported to have a certain prognostic value $(8,9)$. Chung et al $(10)$ used adenovirus vectors to observe the effect of ER $\beta$ protein expression on gene transcription in MCF-7 cells. The authors found that $\mathrm{ER} \beta$ regulated downstream genes, including genes involved in transforming growth factor $\beta$ signaling, cell cycle, apoptosis and the inhibition of cell proliferation. These observations indicated that ER $\beta$ was a poor prognosis factor for carcinogenesis in breast cancer. Jensen et al (11) found that ER $\beta$ positively expressed breast cancer had a higher histological grade than ER $\beta$ negatively expressed breast cancer. In addition, ER $\beta$ mRNA expression levels in cancer tissues were upregulated and the prognosis of $\mathrm{ER} \beta$ and $\mathrm{ER} \alpha$ double positive breast cancer patients was poorer compared with ER $\alpha$ single positive patients. In the present study, the median tumor-free survival time for patients with low ER $\beta$ expression (9.79 years) was significantly higher compared with that of patients with high ER $\beta$ expression (8.01 years; $\mathrm{P}<0.01$ ). This result was in accordance with previous studies and may be caused by the following two aspects. Firstly, G protein may be activated by estrogen through membrane ER $\beta$, rapidly inhibiting the c-Jun N-terminal kinase pathway and preventing the apoptosis of breast cancer cells (12). Secondly, ER $\beta$ may regulate the expression of genes in the Wnt signaling pathway (13). Therefore, ER $\beta$ may regulate the proliferation and invasion of breast cancer cells and an imbalance in its expression acts an important indicator for breast cancer recurrence and metastasis.

A previous study (14) found that ER $\beta$ expression was associated with axillary lymph node metastasis. Axillary lymph node metastasis is an independent indicator for the treatment and prognosis of breast cancer. Prognosis is relatively poor for breast cancer patients with axillary lymph node metastasis. 
Multivariate analysis conducted in the present study indicated that ER $\beta$, HER-2, tumor size, lymph node metastasis, postoperative chemotherapy, radiotherapy and endocrine therapy are independent prognostic factors $(\mathrm{P}<0.05)$. Positive expression of ER $\beta$ and HER-2, larger tumor size, lymph node metastasis, postoperative chemotherapy, radiotherapy and endocrine therapy were risk prognosis factors. This is consistent with previous studies, indicating the positive value of ER $\beta$ in prognosis evaluation.

In summary, for the diagnosis and treatment of breast cancer, ER $\alpha$ is measured as a routine pathology test. The 2012 Breast Cancer National Comprehensive Cancer Network treatment guidelines emphasized that adjuvant systemic treatment should be provided according to the expression of ERs. Based on the observations of the present study, it may be hypothesized that ER $\beta$ is important for the assessment of postoperative treatment options and prognosis. Combined detection of ER $\alpha$ and ER $\beta$ is likely to guide endocrine treatment and prognosis assessment and provide more detailed information for individualized clinical treatment.

\section{Acknowledgements}

The study was supported by a grant from the Natural Science Foundation of Xinjiang Uygur Autonomous Region (no. 2011211A069).

\section{References}

1. Kuiper GG, Enmark E, Pelto-Huikko M, et al: Cloning of a novel receptor expressed in rat prostate and ovary. Proc Natl Acad Sci USA 93: 5925-5930, 1996.
2. Yuan MQ, Ping GF and Nan KJ: Progress in research of estrogen receptor beta and primary liver cancer. Xian Dai Zhong Liu Yi Xue 16: 1826-1829, 2008 (In Chinese).

3. Yager JD and Davidson NE: Estrogen carcinogenesis in breast cancer. New Engl J Med 354: 270-282, 2006.

4. Esslimani-Sahla M, Simony-Lafontaine J, Kramar A, et al: Estrogen receptor beta (ERbeta) level not its ER beta cx variant helps to predict tamoxifen resistance in breast cancer. Clin Cancer Res 10: 5769-5776, 2004.

5. Hopp TA, Weiss HL, Parra IS, et al: Low levels of estrogen receptor beta protein predict resistance to tomoxifen therapy in breast cancer. Clin Cancer Res 10: 7490-7499, 2004.

6. Borgquist S, Holm C, Stendahl M, et al: Oestrogen receptors alpha and beta show different associations to clinicopathological parameters and their co-expression might predict a better response to endocrine treatment in breast cancer. J Clin Pathol 61: 197-203, 2008.

7. Lee $\mathrm{H}$ and Bai W: Regulation of estrogen receptor nuclear export by ligand-induced and p38-mediated receptor phosphorylation. Mol Cell Biol 22: 5835-5845, 2002.

8. Pettersson K and Gustafsson JA: Role of estrogen receptor beta in estrogen action. Annu Rev Physiol 63: 165-192, 2001.

9. Osborne CK and Schiff R: Estrogen-receptor biology: continuing progress and therapeutic implications. J Clin Oncol 23: $1616-1622,2005$.

10. Chung YL, Sheu ML, Yang SC, et al: Resistance to tamoxifen-induced apoptosis is associated with direct interaction between Her-2/neu and cell membrane estrogen receptor in breast cancer. Int J Cancer 97: 306-312, 2002.

11. Jensen EV, Cheng G, Palmieri C, et al: Estrogen receptors and proliferation markers in primary and recurrent breast cancer. Proc Natl Acad Sci USA 98: 15197-15202, 2001.

12. Razandi M, Pedram A and Levin ER: Plasma membrane estrogen receptors signal to antiapoptosis in breast cancer. Mol Endocrinol 14: 1434-1447, 2000.

13. Sun H, Zhang J, Zhan ZG and Hao XS: Estrogen receptor $\beta$ and related genes of its signaling pathway in development of different models of breast cancer. Zhonghua Shi Yan Wai Ke Za Zhi 23: 1422-1423, 2006 (In Chinese).

14. Yang SE and Li X: Expression and significance of ER $\beta$ and HER2 in breast cancer. Zhonghua Zhong Liu Za Zhi 29: 767-768, 2007 (In Chinese). 